International Journal of Agriculture, Environment and Bioresearch

Vol. 5, No. 06; 2020

ISSN: $2456-8643$

\title{
EFFECT OF AGRICULTURAL EXPORT PRODUCTS ON ECONOMIC GROWTH IN NIGERIA (1960 - 2016)
}

\author{
Amao Oyetoun Dunmola ${ }^{1}$ and Oni Timothy Olukunle*2 \\ ${ }^{2}$ Nigerian Institute of Social and Economic Research (NISER) Ibadan, P.M.B 5.U.I.P.O Ojoo, Oyo Road, Ibadan, \\ Nigeria. olukunleniser2012@ gmail.com +2348033950670 \\ ${ }^{1}$ Bioresources Development Centre, Ilorin , +2348038075483 \\ https://doi.org/10.35410/IJAEB.2020.5590
}

\begin{abstract}
Nigeria is generously endowed with abundant natural resources but the effect of the agricultural resources in bringing about economic growth and sustainable development remained unclear. Thus, the main focus of this research work is to quantify the trend and contribution of agricultural export products to economic growth in Nigeria. We analyzed the relationship between Gross Domestic Product (GDP) and agricultural exports for Nigeria by employing Johansen co- integration technique and General Method of Moment (GMM) for the period 19602016. The findings of the study showed that agricultural exports (total) have negative and insignificant effect on economic growth. Also, looking at each sub-sector that makes agricultural sector, the findings revealed that out of four sub-sectors that were used in our model, only beverages and tobacco sub-sector was statistically significant but in a negative direction. It is suggested that agriculture should be given a sustainable and consistent attention to promote agricultural productivity and increased value addition to generate a well-diversified high valued products for increased foreign exchange earnings through increased exports that is needed for sustainable growth and development.
\end{abstract}

Keywords: Economy, Agriculture, Export, Growth, Productivity.

\section{INTRODUCTION}

Nigeria is generously endowed with abundant natural resources including biological and nonbiological resources (Olajide, et al., 2012). Resources depend on importance attached to it. Hence, agriculture constitutes one of the most important sector of the economy. The significance of agricultural resources in bringing about economic growth and sustainable development of a nation cannot be underestimated. It is generally recognized that agricultural sectorcontributes to the growth of the economy, provides employment opportunities for the teaming population, generate export revenue earnings and eradicates poverty in the economy (Olajide, et al., 2012).Abayomi (1997), stated that stagnation in agriculture is the principal explanation for poor economic performance, while rising agricultural productivity has been the most important concomitant of successful industrialization. Oji-Okoro (2011) is of the opinion that agricultural resources have been an important sector in the Nigerian economy in the past decades, and is still a major sector despite the oil boom. Basically it provides employment opportunities for the teeming population, eradicates poverty and contributes to the growth of the economy. The pervasive influence of agriculture on Nigeria's economic and social development has also been 
Vol. 5, No. 06; 2020

ISSN: $2456-8643$

articulated by (Oluwasami, 1966; Olajide, et al., 2012). A strong and efficient agricultural sector would enable a country to feed its growing population, generate employment, earn foreign exchange and provide raw materials for industries. The agricultural sector has a multiplier effect on any nation's socio-economic and industrial fabric because of the multifunctional nature of agriculture (Ogen, 2007; Olajide, et al., 2012).

Agriculture has been defined as the production of food and livestock and the purposeful tendering of plants and animals (Ahmed, 1993; Olajide, et al., 2012). In the same view, Okolo (2004) described agricultural sector as the most important sector of the Nigeria economy which hold a lot of potentials for the future economic development of the nation as it had done in the past. The agriculture sector has been the mainstay of the economy since independence and despite several bottlenecks; it remains a resilient sustainer of the populace. In the 1960s, Nigeria was the world's largest exporter of groundnut, the second largest exporter of cocoa and palm produce and an important exporter of rubber, and cotton (Sekunmade, 2009). More recently, agriculture employs about two-thirds of Nigeria's labour force, contributes significantly to the GDP and provides a large proportion of non-oil earnings (CIA, 2013, Sekunmade, 2009).

The sector has several untapped potential for growth and development in the availability of land, water, labour and its large internal markets. It is estimated that about 84 million hectares of Nigeria's total land area has potential for agriculture; however, only about $40 \%$ of this is under cultivation (FMARD, 2012). Productivity in the cultivated lands is also low due to small farm holdings and primitive farming methods. Nigeria has therefore become heavily dependent on food imports. In addition to diverse and rich vegetation that can support heavy livestock population, it also has potential for irrigation with a surface and underground water of about 267.7 billion cubic meters and 57.9 billion cubic meters respectively (Chauvin, et al., 2012; Lipton 2012). Nigeria's large and growing population provides a potential for a vibrant internal market for increased agricultural productivity. In spite of these opportunities, the state of agriculture in Nigeria remains poor and largely underdeveloped. The sector continues to rely on primitive methods to sustain a growing population with little efforts to add value to primary products that constitute the major non-oil export basket. This has reflected negatively on the productivity of the sector, its contributions to economic growth as well as its ability to perform its traditional role of food supply and food security among others. This state of the sector has been blamed on oil glut and its consequences on several occasions (Falola and Haton, 2008).

In 1960 , petroleum contributed $0.6 \%$ to GDP while agriculture's contribution stood at $67 \%$. However by 1974, the share of petroleum had increased to $45.5 \%$ almost double that of agriculture which had decreased to $23.4 \%$ (Yakub, 2008). It should be clarified that this pattern was not an outcome of increased productivity in the non-agricultural sectors as expected of the industrialization process (Christaensen and Demery, 2007); rather it was the result of low productivity due to negligence of the agriculture sector. The subsectors of the agricultural sector in Nigeria have potentials that give the sector opportunity for growth. According to CBN (2012), between 1960 and 2011, an average of 83.5\% of agriculture GDP was contributed by the crops production subsector making it the key source of agricultural sector growth. The food production role of the agriculture sector depends largely on this subsector as all the staples consumed in the 
nation comes from crop production, $90 \%$ of which is accounted for by small-scale, subsistent farmers.

The growth of Nigeria's non-oil exports has been sluggish and non- encouraging in the postindependence period. It averaged about 2.3\% during 1960 to 1990 but in relative terms, declined systematically as proportion of total exports fell from about $40 \%$ in 1970 to about 5\% in 2010 (World Bank, 2011). A well-developed export sector will provide employment opportunity for the people with the attendant reduction in social cost of unemployment. Earning from export will reduce the strain on the balance of payment position and even improve it (Abogan, et al., 2014). A rewarding export drive in the agricultural sector can turn a hitherto underdeveloped economy into a prosperous economy. Income earned through exporting will help in increasing the level of demand within the economy (Abogan, et al., 2014). An assessment of the trend and patterns of activities in the non-oil sector of Nigeria revealed that despite the various policies, strategies and reform programmes, the contributions of the various sub-sectors of this sector have been dismal, disheartening and below their full potentials. Agriculture that serves as mainstay of the economy in the pre-independence era is still characterized by low productivity. This stems from small farm size with crude and outdated farm implements, lack of access to credit facilities, production machinery and improved inputs by farmers owing to inadequacies of their provision among others (Abogan, et al., 2014).

The challenges of non-oil export sector is not that it is being over shadowed by the oil export trade, but traceable to declining non-oil export and loss of market share in the non-oil trade globally. This is a clear evidence of how the non-oil sector competitiveness of the Nigerian economy has been consistently eroded over the last three decades. A robust and strong export trade is indicative of how competitive the commodities and services are, and how large the scale of the industrial base of an economy is, this is reflected by the comparative advantage possessed by the country. Also, exports of commodities are possible when domestic demand for such are satisfied and surpluses exist in commercial quantities (Abogan, et al., 2014). Thus, the non-oil export sector serves as the hub for exporting these surplus products by the non-oil base of the country's economy. From the mid of 70's to the mid of 80 's, the average annual growth rate of agricultural exports declined by 17 per cent. By 1996, agriculture accounted for only 2 per cent of exports. As agricultural exports shrank from the traditional 12-15 commodities of the 1960s. Nigeria became a net importer of some commodities that it formally exported (Daramola et al., 2007). Also, the market for Nigeria's agricultural exports did not increase appreciably as roughly all of it still goes to the European Union, and almost in its primary form without any appreciate value addition (Daramolaet al., 2007). The major cause of the decline in agricultural exports was the oil price shocks of 1973-74 and 1979, which resulted in large inflow of foreign exchange and neglect of the agricultural sector (Dutch disease). The consequences of this phenomenon was that, owing to the reduced competitiveness of agriculture, Nigeria began to import some of those agricultural products it formally exported and other food crops that it had been self-sufficient in. Between 1970 and 1982 Nigeria lost over 96.6 per cent of her exports in nominal term. Domestic food production also declined substantially, causing the food import bill to attain a high of about \$4billion in 1982. The astronomical increase in imports was financed by oil revenues, which ensured positive current account balances in 1979 and 1980(Daramolaet al., 2007), 
Vol. 5, No. 06; 2020

ISSN: $2456-8643$

As at 1986, the situation had reached a crisis stage dramatizing the ineffectiveness of the policy of industrialization through import substitution. This strategy, conferring protection on importcompeting manufacturing by imposing high duties on finished imports and low duties on raw materials and intermediate goods taxed the exportable goods and agricultural sector crashed. Many manufacturing concerns could no longer operate because of lack of foreign exchange to import raw materials. In the path of reforming agricultural sector back to its original state, different strategies and policies were put in place. These included Seven Points Agenda, FADAMA I, FADAMA II, FADAMA III and Vision 2020 and recently the agricultural promotion policy. The major concern is that Nigerians are still importing food and cash crops that have been exported in the year past. This paper wish to see the reasons behind this issue. Not only that, we all know that before new policy can be setup, there must be a purpose for positive impact. Thus the objective of this paper is to provide answers to the following questions. What are the performances of agricultural export products in the economic growth of Nigeria? What are the factors that are regressing the contributions of government in agricultural sector?

The study is prompted by the discrimination and the neglect of the agricultural sector after the discovery and exploitation of oil in the early 1970s. At this period, labour and capital left agriculture for manufacturing, mining, construction and services. Coupled with this problem is what is referred to as Dutch Disease arising from the overvaluation of Nigerian currency which still remains despite structural adjustments made (Daramolaet al., 2007). Before the present democratic regime was re-elected and a new economic reform agenda was introduced, evidencebased policy making was limited. There was lack of in-depth knowledge and understanding of the role of research in the public sector. Research institutes and universities were isolated from policy-making. Engagement by the private sector concentrates on gaining access to the presidency for special favour rather than pressing for broad improvements in policy (Daramolaet al., 2007). The concern among private agents about government not keeping its word is legitimate, and their concern about policy discontinuities is valid. The study is therefore necessary to provide adequate knowledge of the effect of agricultural exports on economic growth. This will aid policy modification for improving contribution of the agricultural sector to the total revenue generation in the economy. The paper is organised into five sections. Following this introductory section is section two which focused on the research design and methodology adopted. Section three presents the major results of the study. Section four concentrates on discussion of the results while the paper is rounded off in section five with policy recommendations and conclusion.

\section{METHODOLOGY}

\subsection{Types and Source of Data}

Time series data were extracted from joint series databases of Central Bank of Nigeria (NBS), National Bureau of Statistics (NBS) and World Trade Organization (WTO). The data included important variables that influence the sectors of the Nigerian economy. According to the Central Bank of Nigeria, these are official Exchange Rate, Direct Investment, Population Growth, Life Expectancy at Birth, Domestic Credit Available from Financial Institutions, Agricultural Export Products and Gross Domestic Products. Agricultural sector comprises of different subsectors 
which produces goods for exportation. They are Food and Live Animals (FLA), Beverages and Tobacco (BETO), Crude Materials Inedible except Fat (CMINE), Animal and Vegetable Oil and Fat (AVOF). The dataset spanned 1960-2016 (56 years). In order to avoid endogeneity problem that may occur in the data, this research work was analyzed using Econometric property of General Method of Moment (GMM) which is different from the econometric tools used by previous scholars on related issue.

\subsection{Analytical Framework}

\section{Growth accounting framework}

Growth accounting was used to determine the sources of economic growth. In neo- classical growth theory, it measures aggregate output $(\mathrm{Yt})$ in period $\mathrm{Y}$ as a function of capital (Kt), labour (Lt) and total factor productivity (At) assuming that $0<\alpha<1$ and $\mu>0$ :

$$
Y_{t}=A_{t}^{\mu} f\left(K_{t}^{\alpha}, L_{t}^{1-\alpha}\right) \text {. }
$$

However, since the interest of the study is the value added by agriculture to the economy and the value added by agriculture sub-sector to agriculture, we conceptualize aggregate output (Yt) as the sum of the contributions of each sector of the economy. Aggregate output of the economy (Yt) embodies sectoral outputs, and each sectoral output is assumed to be the sum of outputs of its subsectors.

Formally, we specify the aggregate output and sectoral output as:

$Y_{t}=\sum_{t}^{T} Y_{i t}(1.1)$

$Y_{i t}=\sum_{t}^{T} Y_{i j t}$

Where $(\mathrm{Yt})=$ aggregate output of an economy in period $\mathrm{t}$,

(Yit) = output of sector in period $t$

$($ Yijt $)=$ output of sub-sector $\mathrm{j}$ in period $\mathrm{t}$

Assuming that all the outputs of the sectors and sub-sectors made positive contributions to the aggregate output. It is possible that growth in each sector of an economy impacts growth in aggregate output. Likewise, growth in a sub-sector can be the source of growth in another sector. Hence we specify the growth in aggregate output and growth in sectoral output as the first derivative of equation (1.1) and (1.2) as follows:

$$
\begin{aligned}
& \frac{\partial Y_{t}}{Y_{t}}=\sum_{t}^{T} \frac{\partial Y_{i t}}{Y_{i t}} \\
& \frac{\partial Y_{i t}}{Y_{i t}}=\sum_{t}^{T} \frac{\partial Y_{i j t}}{Y_{i j t}}
\end{aligned}
$$


Where $\frac{\partial Y_{t}}{Y_{t}}$ is the growth in aggregate output of an economy in period $t$

$\frac{\partial Y_{i t}}{Y_{\text {it }}}$ is the growth in the output of sector in period $\mathrm{t}$,

$\frac{\partial Y_{i j \mathrm{t}}}{Y_{i j \mathrm{t}}}$ is the growth in output of sub-sector $\mathrm{j}$ in period $\mathrm{t}$.

We expect that the growth in all sectors and sub sectors make a positive contribution to growth in aggregate output. It is also possible that the share (weight) of a sector in the economy, and a sub-sector in a sector, is an important determinant of the contribution of a sector to aggregate growth or a sub-sector to sectoral growth. Thus we formally specify growth in aggregate and sectoral output as expressed below:

$\frac{\partial Y_{t}}{Y_{t}}=\sum_{t}^{T} \frac{Y_{i t}}{Y_{t}} \cdot \frac{\partial Y_{i t}}{Y_{i t}}$

$\frac{\partial Y_{i t}}{Y_{i t}}=\sum_{t}^{T} \frac{Y_{i j t}}{Y_{i t}} \cdot \frac{\partial Y_{i j t}}{Y_{i j t}}$

Where $\frac{Y_{i t}}{Y_{t}}=$ share of the output of a sector in aggregate output in period $t$, $\frac{Y_{i j t}}{Y_{i t}}=$ share of the output of sub-sector $\mathrm{j}$ in the sectoral output in period $\mathrm{t}$,

The weighted growths of the sectors and sub-sectors are expected to contribute positively to growth in the aggregate output.

To estimate equation (1.5) and (1.6), we specify the variables that are important in the sectors of the Nigerian economy as defined by the Central Bank of Nigeria and National Bureau of Statistics. These are agricultural exports, official exchange rate, foreign direct investment, life expectancy at birth, domestic credits available from financial institution and population growth. The subsectors of the agriculture sector are categorized into food and live animal, beverages and tobacco, crude materials, inedible except fat and animal and vegetable oil and fat. We include the value added by these sectors and sub-sectors and estimated them as:

gdpgrow $=$ wagric_egrow + wlebgrow + woergrow + wpopggrow + wfdigrow + wdcfgrow $+e_{i}$ 
agrgrow $=$ wfla_egrow + wbetogrow + wcmine_egrow + wavof_egrow $+\mathrm{e}_{\mathrm{i}}$

Where

gdpgrow $=$ growth in gross domestic product (GDP) in period $t$,

agrgrow $=$ growth in agricultural Output in period $\mathrm{t}$.

wagric_egrow $=$ weighted growth rate of agricultural export in period $\mathrm{t}$

wlebgrow $=$ weighted growth rate of life expectancy at birth in period $t$

woergrow $=$ weighted growth rate of official exchange rate in period $t$

wpopggrow $=$ weighted growth rate of population growth in period $t$

wfdigrow $=$ weighted growth rate of foreign direct investment in period $t$

wdcfgrow $=$ weighted growth in domestic credit available from financial institution in period $\mathrm{t}$.

wfla_egrow $=$ weighted growth rate of food and live animal in period $t$

wbetogrow $=$ weighted growth rate of beverages and tobacco in period $t$.

wcmine_egrow $=$ weighted growth rate of crude material, inedible except fat in

period $\mathrm{t}$.

wafov_egrow $=$ weighted growth rate of animal and vegetable oil and fat in period $\mathrm{t}$.

\subsection{Theoretical Expectations of Variables of the Specified Model.}

In the estimation of the model as specified in equations 1.7 and 1.8, regarding the effect of agricultural export on economic growth in Nigeria, the General Method of Moment (GMM) technique was used. Gross Domestic Product and Agricultural Output represent dependent variables. The independent variables will exert an effect on agricultural exports and hence, gross domestic products. These variables were predicted to have differential effects on agricultural production and sub-sector of agricultural production in Nigeria. The estimation was carried out using E-views 7 econometric computer software. Table2.3 explained the implications, hypothesis, and a priori expectations of the effect of explanatory variables on both the agricultural exports and economic growth in Nigeria.

Table 2.3: Variables and Anticipated Signs

\begin{tabular}{|llc|}
\hline Variable & Variable name & Anticipated sign \\
\hline GDPt & Gross domestic product & \\
FDI $_{t}$ & Foreign direct investment & + \\
OER $_{t}$ & Official exchange rate & + \\
LEB $_{t}$ & Life expectancy at birth & + \\
DCF $_{t}$ & Domestic credit provided by financial & - \\
& institution & + \\
POPG & Population growth & + \\
AGRIC_E & Agricultural export & \\
\hline
\end{tabular}

\section{RESULTS}




\subsection{Description of Variables}

Table 3.1 shows the description of the variables used in the analysis. According to the Table, the mean GDP was $\$ 92.8$ million at market price. The average foreign direct investment was $\$ 2.5745$ million. Average value of official Exchange Rate was \$48.5437milllion. Average value of "Life Expectancy at Birth" remained 45.1543 ages. Domestic mean value of Credit Facilities was $\$ 20.3902$ million while the average population growth was 9.85 million people. Food and Life Animal Export (FLA_E) average value was \$12.2698million, Beverages and Tobacco Export (BETO_E) was \$5.6927million, Crude Material Inedible Except Fat Export (CMINE_E) was \$11.8372million, Animal and Vegetable Oil and Fat Export (AVOF_E) was \$8.4023 and Agricultural export was \$12.9605million respectively.

Table 3.1: Descriptive Analysis of the Variables

\begin{tabular}{|llllllllllll|}
\hline & GDP & FDI & OER & LEB & DCF & PoPG & $\begin{array}{l}\text { LFL } \\
\text { A_E }\end{array}$ & $\begin{array}{l}\text { LBET } \\
\text { O_E }\end{array}$ & $\begin{array}{l}\text { LCMI } \\
\text { N_E }\end{array}$ & $\begin{array}{l}\text { LAVO } \\
\text { F_E }\end{array}$ & $\begin{array}{l}\text { LAG } \\
\text { R_E }\end{array}$ \\
\hline ME & $9.28 \mathrm{e}$ & 2.57 & 48.5 & 45.1 & 20.3 & 9.85 & 12.26 & 5.6927 & 11.837 & 8.4023 & 12.96 \\
A & +10 & 54 & 437 & 545 & 902 & +07 & 98 & & 2 & & 05 \\
MA & $5.70 \mathrm{e}$ & 10.8 & 253. & 52.9 & 48.6 & $1.90 \mathrm{e}$ & 15.70 & 12.600 & 16.200 & 11.100 & 16.70 \\
X & +11 & 326 & 492 & 779 & 718 & +08 & 00 & 0 & 0 & 0 & 00 \\
MI & $4.20 \mathrm{e}$ & - & 0.54 & 36.9 & - & $4.50 \mathrm{e}$ & 7.700 & - & 8.1000 & 1.2000 & 8.700 \\
$\mathrm{~N}$ & +09 & 1.15 & 68 & 750 & 1.60 & +07 & 0 & 3.3000 & & & 0 \\
& & 09 & & & 17 & & & & & & \\
S/D & $1.46 \mathrm{e}$ & 2.15 & 67.7 & 3.98 & 12.4 & $4.17 \mathrm{e}$ & 1.625 & 4.0977 & 1.7894 & 2.3797 & 1.593 \\
EV & +11 & 75 & 913 & 36 & 100 & +07 & 2 & & & & 5 \\
& & & & & & & & & & & \\
& & & & & & & & & & & \\
\hline
\end{tabular}

\subsection{Result of Unit Root Test}

Table 3.2 shows the result from unit root test. "stationarity test" at level form $\mathrm{I}(0)$ of most parameters. The null hypothesis of non-stationalrity is not discarded because majority of the parameters, for the reason that the critical value of Mackinnon assessment aimed at ADF as well as $\mathrm{PP}$ are $(-3.55)$ at $1 \% ;(-2.91)$ at $5 \%$ as well as $(-2.59)$ at $10 \%$. ADF and PP assessment statistics must be bigger than critical value for the null hypothesis to be discarded, or when $\mathrm{P}$ value stands significant at precise level of confidence.

Table 3.2: Unit Root Assessment at level "I (0)" and at "first difference I (1)"

\begin{tabular}{|c|c|c|c|c|}
\hline Parameters & ADF & & Phillips-Pero & \\
\hline & $\begin{array}{l}\text { Test } \\
\text { statistic }\end{array}$ & "p-value" & Test statistic & $\begin{array}{l}\text { "p- } \\
\text { value" }\end{array}$ \\
\hline $\begin{array}{ll}\text { LNGDP_O } & \mathrm{I}(0)\end{array}$ & 0.2337 & 0.972 & 0.4099 & 0.981 \\
\hline
\end{tabular}


International Journal of Agriculture, Environment and Bioresearch

Vol. 5, No. 06; 2020

ISSN: $2456-8643$

\begin{tabular}{|c|c|c|c|}
\hline \multirow{3}{*}{ LNAGRIC_O } & $\mathrm{I}(1)$ & $-7.3281 * * *$ & 0.000 \\
\hline & $\mathrm{I}(0)$ & 0.2963 & 0.976 \\
\hline & $\mathrm{I}(1)$ & $-7.3546 * * *$ & 0.000 \\
\hline \multirow[t]{2}{*}{ LNAGRIC_E } & $\mathrm{I}(0)$ & -0.0329 & 0.948 \\
\hline & $\mathrm{I}(1)$ & $-9.3031 * * *$ & 0.000 \\
\hline \multirow[t]{2}{*}{ FDI } & $\mathrm{I}(0)$ & $-3.6579 * * *$ & 0.008 \\
\hline & $\mathrm{I}(1)$ & $-9.5925 * * *$ & 0.000 \\
\hline \multirow[t]{2}{*}{ LEB } & $\mathrm{I}(0)$ & -1.0061 & 0.744 \\
\hline & I(1) & $-2.8573^{*}$ & 0.057 \\
\hline \multirow[t]{2}{*}{ OER } & $\mathrm{I}(0)$ & 2.5153 & 1.000 \\
\hline & $\mathrm{I}(1)$ & $-4.3206 * * *$ & 0.001 \\
\hline \multirow[t]{2}{*}{ DCF } & $\mathrm{I}(0)$ & -2.4898 & 0.123 \\
\hline & $\mathrm{I}(1)$ & $-6.1412 * * *$ & 0.000 \\
\hline \multirow[t]{2}{*}{ POPG } & $\mathrm{I}(0)$ & $-3.3897 * *$ & 0.016 \\
\hline & $\mathrm{I}(1)$ & $-8.7914 * * *$ & 0.000 \\
\hline \multicolumn{4}{|c|}{ 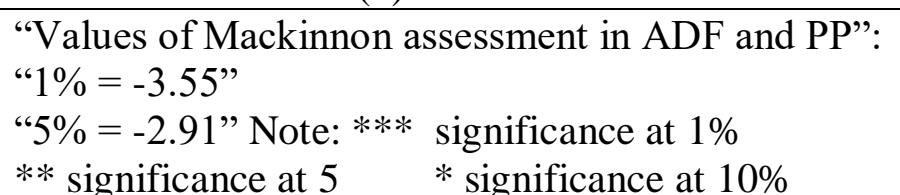 } \\
\hline
\end{tabular}

Majority of the variables had unit root at all levels as the null hypothesis was accepted for majority of the parameters at whichever convenient level of significance, which means the entire parameters are non- stationary at all level. From the same table, the Augmented Dickey Fuller (ADF) along with Phillips-Perron (PP) assessment indicators of first difference in most parameters series information remained important at $1 \%$ only few variables were significant at $5 \%$ and $10 \%$. This indicated that series data stands stationary at first difference, therefore such parameters are measured as integration of I (1) process. The finding corroborates the report of Gemechu (2002), Kagnew (2007) and Fentahun (2011) that discovered stationary data at first difference in favor of labour along with resources.

\subsection{Effect of Total Agricultural Export Products on Total Output (GDP)}

The result in table 3.3 shows the nature of relationship among variables, the correlation of variables revealed that dependent variables (gross domestic product and Agricultural Output) are correlated with independent variables (table 3.3). All other sectors show negative but significant impact on total Gross Domestic Products Output (GDP_O) except Life Expectancy at Birth (LEB) $(\mathrm{t}$ value $=14.72$, coef $=1.0790$ at $\mathrm{p}<0.01)$ that is positive and has significant effect on GDP_O. Total agricultural export product ( $t$ value $=-1.34$, coef $=-0.1321$ at $p>0.1)$ is negative and has insignificant effect on GDP_O.Looking at the sub-sectors, contribution of agricultural export product under Food and Live Animal (FLA_E), all other factors are negative but significant except Life Expectancy at Birth, ( $\mathrm{t}$ value $=13.45$, coef $=1.0698$ at $\mathrm{p}<0.01$ ) that is positive and significant. Food and Live Animals itself is negative and significant $(p<0.1)$. Beverages and Tobacco impact is negative ( $\mathrm{t}$ value $=-2.72$, coef $=-0.1195)$ but significant $(\mathrm{p}<0.01)$ while other factors are also negative but significant. 
International Journal of Agriculture, Environment and Bioresearch

Vol. 5, No. 06; 2020

ISSN: $2456-8643$

Table3.3: Impact of Total Agricultural Export Products on Total Output (GDP)

\begin{tabular}{lllllllllll}
\hline \multicolumn{2}{l}{ LNGDP_O } & LNGDP_O & \multicolumn{2}{l}{ LNGDP_O } & \multicolumn{2}{l}{ LNGDP_O } & \multicolumn{2}{l}{ LNGDP_O } \\
\hline Coef. & T-test & Coef. & T-test & Coef. & T-test & Coef. & T-test & Coef. & T-test \\
-0.3774 & $-3.41 * * *$ & -0.3764 & $-3.47 * * *$ & -0.3424 & $-2.80 * * *$ & -0.3638 & $-3.16^{* * *}$ & -0.3145 & $-2.17 * *$ \\
-0.0091 & $-2.87 * * *$ & -0.0094 & $-2.84 * * *$ & -0.0126 & $-3.34 * * *$ & -0.0086 & $-2.73 * * *$ & -0.0077 & $-1.92 * *$ \\
1.0790 & $14.72 * * *$ & 1.0698 & $13.45 * * *$ & 1.2416 & $14.61 * * *$ & 1.0807 & $14.82 * * *$ & 1.0156 & $10.55 * * *$ \\
-0.0300 & $-3.04 * * *$ & -0.0273 & $-2.60 * * *$ & -0.0235 & $-2.06 * *$ & -0.0341 & $-3.35 * * *$ & -0.0256 & $-2.08 * *$ \\
-2.7534 & $-4.65 * * *$ & -2.6667 & $-4.37 * * *$ & -3.6638 & $-6.25 * * *$ & -2.8921 & $-5.08 * * *$ & -2.8429 & $-4.38 * * *$ \\
-0.1321 & -1.34 & & & & & & & &
\end{tabular}

LNFLA_E

$-0.1310-1.84 *$

LNBETO

LNCMINE_E

$-0.1195-2.72 * * *$

LNAVOF_E

$\begin{array}{llll}-0.1310 & -1.84 * & & \\ & & -0.1195 & -2.72 * * *\end{array}$

CONSTANT

$-9.63$

$-9.04$

26.5136

26.4517

$-0.1141-1.45$

Ad) R-Square

0.903

0.903

0.910

0.902

0.896

F-Statistics

$52.38(0.000)$

$52.53(0.000)$

34

$53.64(0.000)$

32

51.66 (0.000)

34

$48.86(0.000)$

34

Obs.

Note: $* * *$ Significant at $1 \%$

$* *$ Significant at $5 *$ Significant at $10 \%$

Looking at the impact of Crude Materials Inedible except Fat, CMINE_E itself, its effect is negative and insignificant (tvalue $=-1.45$, coef $=-0.1141$ at $p>0.1$ ). Life Expectancy at Birth is positively significant while all other factors are negative withsignificant effect. The effect of Animal and Vegetable Oil and Fat is progressive but negligible (tvalue $=0.19$, coef $=0.0126$ at $\mathrm{p}>0.1$ ). F-statistic for table 3.3 shows that all explanatory variables including agricultural export sub-sector are adequate to explain dependent variables while $\mathrm{R}^{2}$ shows reliability of explanatory variables not less than $90 \%$ i.e. they are significant at $1 \%, 5 \%$ and $10 \%$.

\subsection{Effect of Agricultural Export Products on Agricultural Output}

Table3.4 shows that all factors are negative but significant except Life Expectancy at Birth (LEB) that is positive and significant ( $\mathrm{t}$ value $=14.47$, coe $\mathrm{f}=1.0247$ at $\mathrm{p}<0.01$ ). Concerning the impact of Food and Live Animals Export (FLA_E) on Agricultural Output (AGRIC_O), all variables including Food ad Live Animals exert negative but significant effect on agricultural output $(\mathrm{t}$ value $=-2.31$, coef $=-0.1368$ at $\mathrm{p}<0.05$ ). Life Expectancy at Birth exert positive and significant effect on agricultural output. Effect of beverages and tobacco (BETO) on agricultural output is negative and significant ( $\mathrm{t}$ value $=-2.86$, coef $=-0.1164$ at $\mathrm{p}<0.01$ ). The effect of Population Growth (POPG) is negative and significant $(\mathrm{t}$ value $=-6.51$, coef $=-3.9257$ at $\mathrm{p}<0.01)$. Effect of official 


\section{International Journal of Agriculture, Environment and Bioresearch}

Vol. 5, No. 06; 2020

ISSN: $2456-8643$

Table 3.4: Impact of Agricultural Export Products on Agricultural Output

\begin{tabular}{|c|c|c|c|c|c|c|c|c|c|c|c|}
\hline & \multicolumn{2}{|c|}{ LNAGRI_O } & \multicolumn{2}{|c|}{ LNAGRI_O } & \multicolumn{2}{|c|}{ LNAGRI_O } & \multicolumn{2}{|c|}{ LNAGRI_O } & \multicolumn{3}{|c|}{ LNAGRI_O } \\
\hline LNEDI & $\begin{array}{l}\text { Coef. } \\
-0.2903\end{array}$ & $\begin{array}{l}\text { T-test } \\
-280 * * *\end{array}$ & $\begin{array}{l}\text { Coef. } \\
-0.2892\end{array}$ & $\begin{array}{l}\text { T-test } \\
-285^{*} * *\end{array}$ & Coef. & $\begin{array}{l}\text { T-test } \\
-223^{* *}\end{array}$ & Coef. & $\begin{array}{l}\text { T-test } \\
55 * * *\end{array}$ & Coef. & T-test & \\
\hline OER & -0.0071 & $-2.28 * *$ & -0.0073 & $-2.28 * *$ & -0.0104 & $-2.86 * * *$ & -0.0066 & $-2.14 * *$ & -0.0059 & -1.54 & \\
\hline LEB & 1.0247 & $14.47 * * *$ & 1.0151 & $13.37 * * *$ & 1.1789 & $14.08 * * *$ & 1.0204 & $14.49 * * *$ & 0.9599 & $10.62 *$ & **** \\
\hline LNDCF & -0.0229 & $-2.40 * * *$ & -0.0201 & $-2.00 * *$ & -0.0162 & -1.47 & -0.0273 & $-2.73 * * *$ & -0.0194 & -1.61 & \\
\hline POPG & -3.0247 & $-5.11 * * *$ & -2.9342 & $-4.85 * * *$ & -3.9257 & $-6.51 * * *$ & -3.1698 & $-5.51 * * *$ & -3.1660 & $-4.95 *$ & *** \\
\hline LNAGRIC_E & -0.1379 & $-2.02 * *$ & & & & & & & & & \\
\hline LNFLA_E & & & -0.1368 & $-2.13 * *$ & & & & & & & \\
\hline LNBETO & & & & & -0.1164 & $-2.86 * * *$ & & & & & \\
\hline LNCMINE_E & & & & & & & -0.1206 & -1.69 & & & \\
\hline LN|AVOF_E & & & & & & & & & -0.0121 & -0.20 & \\
\hline CONSTANT & - & -9.54 & - & -8.99 & - & -10.80 & - & -9.83 & - & -6.85 & \\
\hline & 25.0956 & & 25.0313 & & 31.0283 & & 25.1834 & & 23.6501 & & \\
\hline Ad] R-Square & 0.916 & & 0.916 & & 0.923 & & 0.915 & & 0.909 & & \\
\hline F-Sttatistics & $61.42(0$ & 000) & $61.66(0$ & 00) & $63.04(0.1$ & 000) & $60.46(0$. & 00) & $56.18(\mathrm{C}$ & 00) & \\
\hline $\begin{array}{l}\text { Number of } \\
\text { Obs. }\end{array}$ & 34 & & 34 & & 32 & & 34 & & 34 & & \\
\hline
\end{tabular}

Note: *** Significant at $1 \%$

** Significant at $5 \%$

* Significant at $10 \%$

Exchange Rate (OER) is negative and significant ( $\mathrm{t}$ value $=-2.86$, coef $=-0.0104$ at $\mathrm{p}<0.01)$.Influence of foreign direct investment (FDI) ( $\mathrm{t}$ value $=-2.23$, coef $=-0.2534$ at $\mathrm{p}<0.05)$ is negative and significant. Similarly the influence of Domestic Credit provided by Financial Institution (DCF) is negative and insignificant while Life Expectancy at Birth (LEB) (t value $=$ 14.08 , coef $=1.1789)$ is positive and significant.

Effect of crude materials inedible except fat (CMINE) is negative and not significant ( $\mathrm{t}$ value $=$ 1.69, coef $=-0.1206)$. Regarding the contribution of animal and vegetable oil and fat export,(AVOF_E) only Population Growth (POPG) is negative but significant. Effect of AVOF_E is negative and significant while LEB ( $\mathrm{t}$ value $=10.62$, coef $=0.9599$ at $\mathrm{p}<0.01$ ) is positive and significant. F-statistic for this result revealed an adequacy of all parameters used for the explained variable while $\mathrm{R}^{2}$ also support the reliance of all the parameters used and the error terms takes little percentage showing that there are other parameters that are to be added as explanatory variables which are added value to the GDP but not in the variables.

\section{DISCUSSION}


Vol. 5, No. 06; 2020

ISSN: $2456-8643$

This study reveals agricultural export products have unenthusiastic and unimportant influence on expansion of national economic growth. Thisis an undesirable outcome of the agricultural exports on economic growth reflecting unwarranted import reliance. The indication is that the effect of agricultural export products on Gross Domestic Product revealed inconsequential improvement. Agricultural products exportation was discovered to show negligible influence on the expansion of gross domestic product implying that agricultural products exportation have inconsequential value in the development of domestic economy. This pitiable viability ofexports of agricultural products in the economic growth is a pointer to low productivity and low value addition of agricultural export products which were mostly exported in raw forms. A worrisome effect is that agricultural export products (total) is significant on agricultural output but in an inverse direction. Results show that the increased export products do not increase total agricultural output but rather resulted in decrease in total agricultural output by $0.1379 \%$. This might result from underutilization of resources and associated wastages of agricultural export products particularly at harvest and post-harvest stages as well as lack of value addition in the sector.

An agricultural export product needs to be processed to add value to the product which will appreciate and add value to the agricultural sector and hence to gross domestic product (GDP).Food and Live Animals Export as well as Beverages and Tobacco also exert negative effect on the agricultural output. This result of the total agricultural export products is the aggregation of the the effect of agricultural sub-sectorson the agricultural sector. Crude Material Inedible except Fat and Animal and Vegetable Oil and Fat are not significant and also negative.Since these subsectors cannot add value to agricultural output, definitely, they cannot add value to the total GDP. This situation made it clear that the effort towards reviving agricultural sector do not bring about any significant effect on the economic growth that will improve the growth of the country. This is manifested in the low economic growth the country is currently experiencing.

\section{CONCLUSION AND POLICY RECOMMENDATION}

This study was designed to evaluate the influence of exportation of agricultural products on the growth of Nigeria economy from the year 1960 till 2016. Assessment of achievement of agricultural export products on the development of the national economy was carried out, The outcome of the "unit roots test" showed most parameters (LNGDP_O, LNAGRIC_O, LNAGRIC_E, FDI, OER, DCF, POPG,) were stationary in first differences I(1).To avoid spurious and endogeneity regression, General method of moment test was employed and the outcome revealed total agricultural product exports havea depressing and insignificant effect on economic growth in Nigeria.The present study also investigated the effect of the sub-sectors of agricultural export products since the contribution from these sub-sectors makes the agricultural export sector. The result showed that out of the four sub-sectors used for this study which are "Food and life animal, beverages and tobacco, crude material, inedible except fat," all have inconsequential achievement on national economic growth. The negative relationship between agricultural export products and economic growth started from when petroleum was discovered in the country. More importantly, crude oil exploration resulted in Agricultural segment abandonment which turned Nigeria economy to oil dependent economy. All other factors such as 
credit, exchange rate, investment and even population that ought to boost the production and exportation of the products from agricultural sector were unable to grow the nation's economy.This study is recommending that the government as well as the private sectors importing products that can be locally produced should attempt to intensify, add value and diversify as well as encourage production of such products to take total advantage of such sector which will eventually culminate in national economic growth. On the basis of the findings of the study, the following recommendations are proffered.

- Government should encourage young school leavers and make agriculture attractive to them especially in the production of cocoa, textile, wood, lumber and cork and coffee.

- Government should urgently see to the need of adding value to agricultural products through agro- processing.

- Appropriate exchange rate policies should be put in place for better economic performance.

- Government should ensure efficient and effective human resources for robust economic growth.

- Government should discourage the importation of food crops, especially those that can be produced locally.

- Improved/hybrid inputs should be given to farmers at the lower rate and it must be without sentiments.

- For global competitiveness, local producers should be trained the improved method of production, processing, preservation, and packaging to improve the quality and quantity that will attract more revenue for enhancing economic growth.

- Modern machines and technologies to improve the quality and quantity of products at low cost of production should be introduced by government.

\section{REFERENCES}

Abayomi, O. (1997). "The Agricultural Sector in Nigeria: The way forward”. CBN Bulletin, 21:14-25.

Abogan, O. P., Akinola, E. B., and Baruwa, O.I. (2014). Non-oil export and Economic Growth in Nigeria (1980 - 2011), Journal of Research in Economics and international Finance, 3(1), Pp. 1-11.

Adesuoji, A. A. and Sotubo, O. D. (2013) Non-oil exports in the economic growth of Nigeria: A study of agricultural and mineral resources. Journal of Educational and Social Research. 2013;3(2):403-418.

Ahmed, Y. O. (1993). "Bank of the North Pamphlets on Agricultural Financing Various Circulars and Policy Guidelines on Agricultural Financing in Bank of the Norh Limited." A paper delivered at Seminal at Bank of the North Human Resources and Development Centre by (Agric, Officer, Bank of the North Limited)

Central Bank of Nigeria (2012). Statistical Bulletin. Available at: www.centralbank.org.

Charuvin,N., Mulangu, F and Porto, G. (2012, February). Food Production and Consumption

Trends in Sub-Saharan Africa: Prospects for the Transformation of the Agricultural Secto. UNDP working paper for African Human Development Report, Pp. 1-74. 
CIA. (2013). The World Fact Book. Retrieved March 3, 2013 from https://www.cia.giv/library/publications/the-world-factbook/goes/ni.html

Daramola, A., Ehui, S., Ukeje, E. and McIntire, J. (2007). Agricutural export potential in nigeriapp $2-10$.

FMARD (2016). The agriculture promotion policy (2016 - 2020) pp 1-18

Lipton, M. (2012). Learning from others: increasing Agricultural Productivity for Human Development in Sub-Saharan. United Nations Development Programme, Regional Bureau for African. $\quad$ http://web.undp.org/africa/knowledge/WP-2012-007-lipton-AgricultureProductivity.pdf.

Loto M. A. (2011) The impact of economic downturn on the performance of agricultural export in the Nigerian economy (a quarterly empirical analysis). Journal of Emerging Trends in Economics and Management Sciences. ;2(6):504-510.

Oji-Okoro Izuchukwu (2011) Analysis of the Contribution of Agricultural Sector on the Nigerian Economic Development World Review of Business Research Vol. 1. No. 1. Pp. 191 200

Olajide, O, Akinlabi, B. and Tijani, A. (20012). Agricultural Resource and Economic Growth in Nigeria European Scientific Journal, 8(22), 103-115

Onodugo, V., Ikpe, M., Anowor, O. F. (2013) Non-oil export and economic growth in Nigeria: A time series econometric model. International Journal of Business Management and Research. ;3(2): 115-124.

Sekunmade, A. (2009). The effects of petroleum dependency on agricultural trade in Nigeria: An error correlation modeling (ECM) approach. Scientific Research and Essay, 4(11), $1385-1391$ 